ROCZNIK POLSKO-NIEMIECKI 2019, nr 27

ISSN 1230-4360

DOI 10.35757/RPN.2019.27.1.08

\author{
Aleksandra Kruk \\ Instytut Politologii Uniwersytetu Zielonogórskiego \\ ORCID 0000-0002-7545-941X
}

\title{
Koordynator ds. współpracy polsko-niemieckiej - działalność Dietmara Woidkego
}

Funkcja koordynatora ds. polsko-niemieckiej współpracy społecznej i przygranicznej została wyodrębniona w niemieckim urzędzie spraw zagranicznych w 2004 roku i wiązała się z wejściem Polski do Unii Europejskiej. Inicjatywę wyłonienia tej funkcji przypisuje się socjaldemokracie Mathiasowi Platzeckowi, ówczesnemu premierowi Brandenburgii ${ }^{1}$. W niemieckim urzędzie spraw zagranicznych koordynatorzy są powoływani, by zajmować się obszarami polityki zagranicznej, które zostały uznane za wymagające szczególnych działań, i często obok określenia koordynator funkcjonuje też termin pełnomocnik. W internacjologii, ale także polityce wewnętrznej zadania koordynacyjne są analizowane, by uchwycić ich istotę i specyficzne cechy. Robert K. Tabaszewski zaznaczył, że rozumienie roli koordynacji ma źródło w łacinie, gdzie coordinatio oznacza uzgadnianie, natomiast jej zastosowanie wykorzystano m.in. w prakseologii oraz politologii². Renata Włoch zwróciła uwagę, że „funkcja koordynacyjna obejmuje dążenia zmierzające do nadania spójności i aktywności państwa na arenie międzynarodowej”’. Jan Borkowski zauważył: „koordynacja to proces sformalizowany i uregulowany konstytucyjnymi normami prawnymi, ustawami bądź aktami niższego rzędu i obowiązujący wszystkie strony uczestniczące w kształtowaniu polityki w danej

Woidke zu Antrittsbesuch in Warschau, „Lautsitzer Rundschau“, 24 lutego 2014.

2 R.K. Tabaszewski, System koordynacji polityk Unii Europejskiej. Studium polityczno-prawne, „Zeszyty Naukowe FDM” 2012, nr 1.

3 R. Włoch, Funkcje polityki zagranicznej państwa, w: R. Zięba, Wstęp do teorii polityki zagranicznej państwa, Wydawnictwo Adam Marszałek, Toruń 2004, s. 132. 
dziedzinie. Pełna koordynacja powinna obejmować przy tym wszystkie fazy takiej polityki, a więc programowanie, proces decyzyjny, realizację i jej kontrolę"4. Istotne jest też spostrzeżenie badacza: „Funkcjonowanie organu odpowiedzialnego za koordynację działań innych organów, które posiadają własne, określone ustawowo kompetencje w dziedzinie polityk sektorowych, wywołuje obawy, a czasem realne przypadki naruszania kompetencji własnych, co powoduje niechęć wobec poddawania się mechanizmowi koordynacji ${ }^{5 "}$.

W opracowaniu służb naukowych Bundestagu stwierdzono, że nie ma prawnej definicji terminu pełnomocnik. Istnieje potrzeba określenia ich statusu, który jest specyficzny, odmienny od prawnych uregulowań dotyczących pełnomocników wyodrębnionych na mocy Ustawy zasadniczej (np. w art. 45b pełnomocnik ds. sił zbrojnych), pełnomocników działających przy parlamencie lub pełnomocników działających w poszczególnych resortach według hierarchicznego przypisania funkcji, np. pełnomocnika ds. równouprawnienia czy zwalczania korupcji ${ }^{6}$. Natomiast współpracę z koordynatorami rządu, koordynatorami federalnymi oraz koordynatorami i koordynatorkami rządu federalnego określa art. 21 Wspólnego Regulaminu (Gemeinsame Geschäftsordnung, $G G O$ ). Jest to dosyć ogólne stwierdzenie, że pełnomocnicy zostają wcześniej poinformowani o swoich zadaniach oraz przekazują ministerstwu informacje związane $\mathrm{z}$ wykonywanymi obowiązkami. Natomiast precyzyjnego określenia funkcji pełnomocników brakuje ${ }^{7}$. W przypadku urzędu spraw zagranicznych wyodrębniono ośmiu pełnomocników. Ich status i obowiązki są zróżnicowane, wynikają z prawnego umocowania stanowiącego podstawę powołania. Pełnomocnika rządu ds. rozbrojenia i kontroli zbrojeń powołuje się na czas nieokreślony na mocy decyzji rządu (Kabinettbeschluss, 14 lipca 1965). Pełnomocnik ds. współpracy francusko-niemieckiej jest powoływany na mocy decyzji rządu oraz umowy międzynarodowej (Traktat elizejski z 1963 roku) na czas trwania kadencji Bundestagu. Pełnomocnik ds. praw człowieka i pomocy humanitarnej jest powoływany na mocy decyzji rządu na czas trwania kadencji Bundestagu (Kabinettbeschluss 24 lutego 2016). Koordynator ds. międzyspołecznej współpracy z Rosją, Azją Centralną oraz państwami Partnerstwa Wschodniego jest powoływany przez rząd na czas kadencji Bundestagu (Kabinettbeschluss, 29 stycznia 2014). Pełnomocnik ds. niemiecko-amerykańskiej współpracy międzyspołecznej, kulturalnej i związanej z polityką informacyjną jest powoływany przez rząd na czas nieokreślony (Kabinettbeschluss 30 kwietnia 2014). Specjalny pełnomocnik rządu ds. Afganistanu i Pakistanu jest powoływany przez gabinet (Kabinettbeschluss 15 lipca 2015), podobnie jak specjalny pełnomocnik ds. przewodniczenia Organizacji Bezpieczeństwa i Współpracy

\footnotetext{
4 J. Borkowski, Koordynacja polskiej polityki integracji europejskiej, „Studia Europejskie” 1998, nr 2, s. 12.

Ibidem.

6 P. Robbe, Bundesbeauftragte und Beauftragte der Bundesregierung. Aktualisierung des Infobriefs „Bundesbeauftragte und Beauftragte der Bundesregierung” (WD 3 - 367/08). Stan z 6 grudnia 2010 roku.

7 Art. 21 Gemeinsame Geschäftsordnung der Bundesministerien, https://www.bmi.bund.de/SharedDocs/Downloads/DE/Veroeffentlichungen/ggo.pdf?_blob=publicationFile (dostęp: 15 września 2017).
} 
w Europie (Kabinettbeschluss 11 grudnia 2014) ${ }^{8}$. Natomiast pełnomocnika ds. międzyspołecznej i przygranicznej współpracy z Polską powołuje się na czas kadencji Bundestagu. Podlega on ministrowi spraw zagranicznych. Cornelia Pieper była powołana rozporządzeniem urzędu spraw zagranicznych, natomiast dr Dietmar Woidke decyzją rządu (Kabinettbeschluss, 29 stycznia 2014).

Dietmar Woidke przejął obowiązki po Cornelii Pieper. Należało do nich pielęgnowanie kontaktów międzyspołecznych oraz dbanie o wizerunek państwa partnerskiego i relacji polsko-niemieckich $\mathrm{w}$ mediach $\left(\right.$ public diplomacy ${ }^{10}$ ). Jego funkcja przewiduje także koordynowanie prac Polsko-Niemieckiej Komisji Międzyrządowej ds. Współpracy Regionalnej i Przygranicznej, której podlegają cztery Komitety (ds. Współpracy Międzyregionalnej, ds. Współpracy Przygranicznej, ds. Gospodarki Przestrzennej oraz Komitet ds. Edukacji), odpowiadające za stan współpracy polsko-niemieckiej. Gesine Schwan i Cornelia Pieper - poprzedniczki Woidkego - były koordynatorkami, gdy zapoczątkowane po zjednoczeniu Niemiec kontakty z Polską, oparte na traktacie granicznym z 1990 roku oraz na Traktacie o dobrym sąsiedztwie i przyjaznej współpracy z 1991 roku, przyniosły pozytywny rezultat w postaci wstąpienia Polski do Unii Europejskiej. Zamiar zwiększenia kontaktów i rozwoju współpracy został osiągnięty. Drogowskazem dla działalności Woidkego było m. in. „Wspólne Oświadczenie Okrągłego Stołu w sprawie wspierania obywateli niemieckich polskiego pochodzenia i Polaków w Niemczech oraz niemieckiej mniejszości w Polsce" z 12 czerwca 2011 roku. Raporty dotyczące rezultatów współpracy były publikowane w komunikatach, deklaracjach, zaleceniach i protokołach na temat realizacji polsko-niemieckiego „Programu Współpracy”, które powstawały w ramach konsultacji międzyrządowych. Schwan i Pieper koordynowały i inicjowały działania prowadzące do porozumienia, pojednania i zbliżenia między polskim i niemieckim społeczeństwem, a także zwiększenia aktywności na pograniczu polsko-niemieckim. Obie cieszyły się poparciem wśród polskich elit politycznych. Gesine Schwan popierali Adam Daniel Rotfeld, Władysław Bartoszewski czy Romana Kuźniar, Cornelię Pieper - Marek Prawda. Koordynatorki podejmowały się roli mediatora $\mathrm{w}$ tak trudnych kwestiach, jak polityka historyczna, np. upamiętnianie wysiedlonych po wojnie z Polski Niemców. Schwan, jako była rektor Uniwersytetu Viadrina, rozumiała znaczenie edukacji w kształtowaniu postaw otwartości oraz przełamywaniu stereotypów $\mathrm{w}^{11}$.

W. Richter, Deutscher OSZE-Vorsitz 2016. Strategische Herausforderungen, „SWP-Aktuell”. 7. Februar 2016.

$9 \quad$ Liste der Beauftragten der Bundesregierung, der Bundesbeauftragten sowie der Koordinatoren / Koordinatorinnen der Bundesregierung nach $\S 21$ Abs. 3 Gemeinsame Geschäftsordnung der Bundesministerien (GGO)file:///C:/Users/Ola/Downloads/beauftragte-der-bundesregierung.pdf (dostęp: 15 września 2017).

10 Beata Ociepka przywołała definicję public diplomacy, którą stosował Daniel Ostrowsky: „całość działań państwowych aktorów działających w sferze publicznej i służących wzmocnieniu miękkiej siły państwa, na rzecz którego działają...”. Por. B. Ociepka, Miękka siła i dyplomacja publiczna Polski, Wydawnictwo Naukowe Scholar, Warszawa 2013, s. 69; R. Łoś, Soft power we współczesnych stosunkach międzynarodowych, Wydawnictwo Uniwersytetu Łódzkiego, Łódź 2017, s. 98-105.

11 P. Robbe, Bundesbeauftragte..., s. 60; A. Kruk, Koordynator ds. Wspótpracy z Polska - o dziataniach Gesine Schwan i Cornelii Pieper, w: eadem (red.), Ministerstwa spraw zagranicznych 


\section{Vita politica Dietmara Woidkego}

Wychowany w komunistycznych Niemczech Dietmar Woidke niejednokrotnie w wywiadach zwracał uwagę na wpływ polityki na jego życie. Polityk urodził się w Naundorf ${ }^{12}$ w pobliżu przygranicznego miasteczka Forst w 1961 roku. Jego dziadek był w Wehrmachcie. Stąd polityk niejednokrotnie wypowiadał się o potrzebie przezwyciężenia społecznych traum będących konsekwencją II wojny światowej oraz komunistycznych rządów w NRD. Zainteresowanie wyznaniem ewangelickim pojawiło się u niego dopiero $w$ dojrzałych latach. W latach siedemdziesiątych za sprawą wprowadzenia ruchu bezwizowego na granicy NRD z Polską chłopak często odwiedzał Gubin. Kiedy w Polsce wprowadzono stan wojenny, Woidke odbywał służbę wojskową w Cottbus ${ }^{13}$.

Do SPD wstąpił w 1993 roku, w tym samym roku uzyskując stopień doktora nauk rolniczych po studiach na Uniwersytecie im. Humboldta. W wyniku wyborów do Landtagu w 1994 roku został posłem i w kolejnych wyborach - w 1999, 2004, 2009 i 2014 roku odnawiał mandat wyborczy, należąc do najliczniejszego i sprawującego władzę ugrupowania w krajowym parlamencie. Był ministrem rolnictwa w latach 2004-2010, a od 2010 do 2013 roku ministrem spraw wewnętrznych. Rządy w Brandenburgii przejął w 2013 roku po socjaldemokratach: Manfredzie Stolpem (1990-2002) i Mathiasie Platzecku (2002-2013). Stolpe był znany z działań dążących do poprawy relacji z Polską i wspierał działalność regionów na pograniczu polsko-niemieckim. 17 czerwca 1991 roku uczestniczył w podpisaniu Traktatu o dobrym sąsiedztwie, a także dążył do intensyfikacji współpracy w regionie Odry poprzez zaproponowanie realizacji tzw. planu Stolpego. Jego propozycje były analizowane przez przedstawicieli środowisk naukowych i politycznych, m.in. Mariana Eckerta, Czesława Osękowskiego czy Janusza Dobosza. Wśród socjaldemokratów z Brandenburgii kwestie współpracy z Polską często figurowały $\mathrm{w}$ agendzie politycznych debat ${ }^{14}$. 14 września 2014 roku w Brandenburgii odbyły się wybory, które doprowadziły do wyłonienia rządu SPD i Die Linke. Po porażce liberałów w wyborach parlamentarnych w 2013 roku Cornelia Pieper nie mogła kontynuować funkcji koordynatora, ponieważ jej ugrupowanie poniosło klęskę w wyborach i znalazło się w opozycji pozaparlamentarnej. Zakończył się trwający od 2009 do 2013 roku czas rządów CDU/CSU i FDP, a władzę przejęła Wielka Koalicja (chadecja i socjaldemokracja). Dietmar Woidke jako premier Brandenburgii i socjaldemokrata spełniał zarówno kryterium polityczne, które umożliwiło mu przyjęcie nowej funkcji, jak

wobec wyzwań XXI wieku, Wyższa Szkoła Studiów Międzynarodowych w Łodzi, Łódź 2013, s. 304-317; K.P. Marczuk, Wspótpraca transgraniczna Polski i RFN w obszarze bezpieczeństwa wewnętrznego, „Krakowskie Studia Międzynarodowe” 2016, nr 2, s. 93-104; C. Trosiak, Pogranicze polsko-niemieckie po drugiej wojnie światowej (lata 1944-1995), Wydawnictwo Naukowe UAM, Poznań 1999, s. 164-165.

12 Miejscowość o nazwie Naundorf znajduje się także w pobliżu Lipska.

13 B. Kerski, A. Szczepański, Rozmowa „Dialogu” z premierem Brandenburgii Dietmarem Woidke, koordynatorem rządu federalnego ds. wspótpracy polsko-niemieckiej, „Dialog” 2015, nr 1, s. 26-31.

14 W. Hładkiewicz, A. Ilciów, Problem pojednania polsko-niemieckiego w działalności społeczno-politycznej premiera Brandenburgii Manfreda Stolpe, „Rocznik Lubuski” 2012, t. 38, s. 101-115. 
i merytoryczne. Został trzecim niemieckim politykiem (po Gesine Schwan i Cornelii Pieper), powołanym do koordynowania polsko-niemieckich kontaktów międzyspołecznych i przygranicznych. Do pełnienia obowiązków został powołany 29 stycznia 2014 roku. W Brandenburgii znany był z zajmowania się polityką wewnętrzną i popierania reformy administracyjnej, która polegała na zmniejszeniu liczby powiatów ${ }^{15}$. Reprezentowany przez niego kraj związkowy graniczy z Polską, a w konstytucji Brandenburgii pojawił się postulat współpracy ze wschodnim sąsiadem ${ }^{16}$. Polityk powoływał się na art. 2 ust. 1 brandenburskiej konstytucji: Artykuł 2 (Zasady konstytucyjne) Brandenburgia jest krajem swobód demokratycznych, praworządnym, socjalnym, zobowiązanym ideałom pokoju i sprawiedliwości, ochronie środowiska naturalnego i kultury, dążącym do współpracy z innymi narodami, a w szczególności z polskim sąsiadem.

Wygłaszając exposé rządu, chwalił osiągnięcia Stolpego i Platzecka oraz wspominał, że dorastał $\mathrm{w}$ pobliżu polsko-niemieckiej granicy. Zadeklarował wolę kontynuacji współpracy z Polską i zaznaczał: „zażyłe i przyjazne relacje z naszymi sąsiadkami i sąsiadami leżą mi szczególnie na sercu"' " Zwracał też uwagę na dziesięciolecie Partnerstwa Brandenburgii z Wielkopolską ${ }^{18}$. W jego wypowiedziach pojawiło się stwierdzenie, że Brandenburgia to „sejsmograf” relacji polsko-niemieckich. Dlatego wyraził zadowolenie z powodu powierzenia mu przez Franka-Waltera Steinmeiera funkcji koordynatora. Gdy przejął zadania po swoich poprzedniczkach, pojawiło się pytanie, na ile jego doświadczenie i umiejętności wpłyną na realizację obowiązków koordynatora? Jaką spośród ról politycznych zdecyduje się realizować? Na ile słuszne było kojarzenie go z polityką wewnętrzną i czy odnajdzie się jako kreator i pośrednik działań międzynarodowych? A także, czy tworzona od 2004 roku wizja współpracy koordynatorów po obu stronach Odry i Nysy Łużyckiej wystarczająco okrzepła i nabrała właściwego wymiaru instytucjonalnego?

Rozpoczynając działalność Woidke zwrócił uwagę, że zajmował się sprawami polsko-niemieckimi w ramach funkcji premiera Brandenburgii oraz zasiadając od 2010 roku w Bundesracie. Po zjednoczeniu Niemiec wizja rozwoju Brandenburgii była oparta na idei integracji europejskiej i propagowania rozszerzenia UE o Polskę. Brandenburczycy, podobnie jak Polacy, uczyli się korzystać z europejskich środków finansowych i rozwijać współpracę transgraniczną. Filary Unii Europejskiej sprzyjały intensyfikacji kontaktów, uczeniu się od siebie i podejmowaniu wspólnych wyzwań. Mimo że w Brandenburgii po 1990 roku nie wszyscy byli euroentuzjastami i część mieszkańców

15 T. Metzner, Die Methode Woidke, „Der Tagesspiegel”, 3 lipca 2017.

16 Konstytucja Kraju Związkowego Brandenburgia z dnia 20 sierpnia 1992 r. (Dziennik Ustaw i Rozporządzeń [GVBL] I, s. 298), zmieniona po raz ostatni Ustawą z dnia 18 marca 2015 r. (Dziennik Ustaw i Rozporządzeń I nr 6), https://www.landtag.brandenburg.de/media_fast/5701/ Verfassung_polnisch.pdf (dostęp: 11 września 2017); I. Janicka, Niemieckie kraje związkowe. Struktura terytorialno-administracyjna, Wydawnictwo Adam Marszałek, Torun 2009, s. 62-70.

17 Regierungserklärung des Ministerpräsidenten des Landes Brandenburg Dr. Dietmar Woidke anlässlich der 80. Sitzung des Landtages Brandenburg am 29. August 2013, http://www.dielinke-brandenburg.de/fileadmin/Newsletter/regierungserklaerung-woidke.pdf (dostęp: 11 września 2017).

18 Ibidem. 
tego kraju związkowego obawiała się rozszerzenia UE, to przeważyły głosy, że rozszerzenie zdynamizuje rozwój gospodarczy w obszarze przygranicznym. Profesor Jochen Franzke z Uniwersytetu w Poczdamie ocenił, że wzrost kontaktów Bandenburgii z Polską „mimo postępów nie zadowala”, a wśród społeczności z Brandenburgii i Polski można obserwować „reakcje polagające na odgradzaniu się od siebie”"19. Dlatego misja Woidkego jako łącznika środowisk z Polski i Niemiec jest dużym wyzwaniem. Po 2013 roku, gdy w Niemczech zaczęła zdobywać poparcie eurosceptyczna partia Alternatywa dla Niemiec (Alternative für Deutschland, AfD), polityk starał się bronić wizję polsko-niemieckiej współpracy w ramach Unii Europejskiej. Oceniał, że AfD jest ugrupowaniem bardziej niebezpiecznym od Niemieckiej Unii Ludowej (Deutsche Volksunion, DVU) czy Narodowodemokratycznej Partii Niemiec ((Nationaldemokratische Partei Deutschlands, NPD). Zarzucał AfD, że sprzeniewierza się niemieckiej kulturze otwartości, a także krytykował stowarzyszenie Patriotycznych Europejczyków przeciw Islamizacji Zachodu (Patriotische Europäer gegen die Islamisierung des Abendlandes, czyli PEGIDE) ${ }^{20}$.

Woidke uważał, że przyjmie rolę pośrednika, aby zintensyfikować współpracę między polskimi i niemieckimi instytucjami. W rozmowie z Basilem Kerskim oraz Arkadiuszem Szczepańskim wskazał cztery priorytety swojej aktywności: sprawy młodzieży, nauczanie języków, transport i bezpieczeństwo ${ }^{21}$. Woidke, obejmując funkcję koordynatora wiosną 2014 roku, oceniał stan współpracy polsko-niemieckiej pozytywnie i zwracał uwagę na porozumienie między obozami rządzącymi w Polsce i Niemczech. W Polsce władzę sprawowały Platforma Obywatelska i Polskie Stronnictwo Ludowe. Jednak wkrótce nastąpiły zmiany personalne. Piotr Stachańczyk, który złożył wizytę Dietmarowi Woidkemu w Poczdamie 2 lipca 2014 roku $^{22}$ został Koordynatorem ds. Polsko-Niemieckiej Współpracy Transgranicznej i Regionalnej, a Władysław Bartoszewski pozostał koordynatorem ds. dialogu międzynarodowego ${ }^{23}$. Gdy Stachańczyk w lipcu 2015 roku zrezygnował z pracy w Ministerstwie Spraw Wewnętrznych i Administracji (MSWiA), pojawił się wakat i Woidke przez kilka miesięcy pracował bez swojego odpowiednika po polskiej stronie. Taka współpraca stała się, zdaniem Woidkego, „,bardziej skomplikowana"24. Dopiero 14 stycznia 2016 roku w wywiadzie udzielonym gazecie

19 J. Franzke, Brandenburg und Europa. Wie weiter?, w: J. Franzke, Europa in der Denkpause. Wege aus der Verfassungskrise, WeltTrends Verlag, Potsdam 2005, s. 106.

20 Dietmar Woidke über die AfD Gefährlicher als NPD und DVU, http://www.taz.de/!5025665/ (dostęp: 2 września 2018); T. Metzner, Reden aber nicht zu viel, „Der Tagesspiegel”, 23 lutego 2016, https://www.pressreader. com (dostęp: 9 stycznia 2017); T. Metzner, BER und Flüchtlinge: Woidke fliegt zur EU, „Der Tagesspiegel”, 23 lutego 2016, http://www.tagesspiegel.de/berlin/ber-und-fluechtlinge-woidke-fliegt-zur-eu-redenaber-nicht-zu-viel/13006498.html (dostęp: 9 stycznia 2017).

21 B. Kerski, A. Szczepański, Rozmowa z Dietmarem Woidke..., s. 26.

22 Dziennikarz „Gazety Prawnej” w rozmowie z Anną Wolff-Powęską zwrócił uwagę, że premier Donald Tusk koordynację współpracy Polski z RFN przeniósł z MSZ do MSWiA.

23 Dietmar Woidke trifft polnischen Koordinator für polnisch-deutsche grenznahe Zusammenarbeit, 3. Juli 2014, http://www.auswaertiges-amt.de/DE/AAmt/Koordinatoren/D-PL-Koordinator/ Aktuell/140703_Stachanczyk.html (dostęp: 13 września 2017).

24 „EU-Verfahren gegen Polen. „Ratschläge von außen zu geben, ist falsch”, „Märkische Allgemeine", 14. Januar 2016, http://www.maz-online.de/Brandenburg/Ratschlaege-von-aussen-zugeben-ist-falsch (dostęp: 14 września 2017). 
„Märkische Allgemeine” oświadczył, że dostrzegł zapowiedź, że zostanie wyłoniony koordynator. Brak koordynatora po stronie polskiej wiązał się z przebiegającymi jesienią 2014 roku zmianami personalnymi na polskiej scenie politycznej. Podczas gdy w wyniku wyborów do parlamentu krajowego Brandenburgii Dietmar Woidke pozostał na stanowisku premiera i ponownie powołał rząd SPD i Die Linke, w Polsce rozpoczęła się rotacja stanowisk.

Tabela 1. Wyniki wyborów w Brandenburgii z 14 września 2014 roku

\begin{tabular}{|l|c|}
\hline \multicolumn{1}{|c|}{ Partia polityczna } & Liczba miejsc w Landtagu \\
\hline SPD & 30 \\
\hline Die Linke & 17 \\
\hline CDU & 21 \\
\hline FDP & 0 \\
\hline Grüne/BPO & 6 \\
\hline BVB/Freie Wähler & 3 \\
\hline AfD & 11 \\
\hline
\end{tabular}

Źródło: Ergebnis der 6. Wahl zum Landtag in Brandenburg am 14. September 2014, https://www. bundeswahlleiter.de/service/landtagswahlen/land-12.html\#a27eba88-c457-41a1-b96c-d90dc50947e7 (dostęp: 11 września 2017).

Ważnym wydarzeniem była rezygnacja Donalda Tuska z pełnienia funkcji premiera RP i jego wybór na urząd Przewodniczącego Rady Europejskiej. 1 września 2014 roku Dietmar Woidke, gratulując Donaldowi Tuskowi objęcia nowej funkcji, zwrócił uwagę, że osiągnął podobny sukces do Jerzego Buzka, byłego Przewodniczącego Parlamentu Europejskiego ${ }^{25}$. Gdy gratulował 22 września 2014 roku premier Ewie Kopacz objęcia urzędu, zaznaczył, że zależy mu na kontynuacji współpracy. Priorytetami określił działania zmierzające do poprawy znajomości języków, infrastruktury i zwiększenia bezpieczeństwa w obszarze przygranicznym ${ }^{26}$. Jej rząd nie przetrwał jednak kolejnych wyborów parlamentarnych. Od 16 listopada 2015 roku na czele polskiego rządu stanęła Beata Szydło z Prawa i Sprawiedliwości. Woidke, mając świadomość różnych wizji polityki wobec RFN, które reprezentują partie PiS i PO, musiał uwzględnić zmiany na polskiej scenie politycznej. Pojawiło się pytanie, na ile wizja status quo i podzielana przez Dietmara Woidkego i Władysława Bartoszewskiego w kwietniu 2014 roku wizja współpracy przetrwa? Obaj politycy zadeklarowali wtedy, że stosunki polsko-niemieckie układają się pozytywnie. Zarówno strona niemiecka, jak i PO często powoływały się na współpracę dwustronną opartą na Traktacie o dobrym sąsiedztwie i przyjaznej

25 Koordinator Woidke begrüßt Wahl Tusks zum Europäischen Ratspräsidenten 1. September 2014, http://www.auswaertiges-amt.de/DE/AAmt/Koordinatoren/D-PL-Koordinator/Aktuell/140 901-Wahl-Tusk.html (dostęp: 13 września 2017).

26 Dietmar Woidke gratuliert der neuen polnischen Ministerpräsidentin Ewa Kopacz, 22. September 2014, http://www.auswaertiges-amt.de/DE/AAmt/Koordinatoren/D-PL-Koordinator/Aktuell/140922_Gratulation-Kopacz.html (dostęp: 13 września 2017). 
współpracy z 1991 roku oraz na współpracę w Unii Europejskiej. Jednak narastający eurosceptycyzm i przejęcie władzy przez PiS spowodowały zmianę dyskursu. Woidke reprezentował stanowisko: „Polski rząd został wybrany demokratycznie. Lepiej jest rozmawiać ze sobą niż o sobie"27. Od 2014 roku odnosi się on do współpracy polsko-niemieckiej dynamicznie, reagując na wydarzenia, jak i koordynując i firmując działania realizowane przez liczne instytucje zajmujące się współpracą polsko-niemiecką, które zostały bardzo często zaplanowane z dużym wyprzedzeniem.

12 stycznia 2016 roku we wrocławskim zjeździe „Partnerstwa Odry” uczestniczyło 4 nowych wojewodów - Paweł Hreniak (województwo dolnośląskie), Władysław Dajczak (województwo lubuskie), Piotr Jania (województwo zachodniopomorskie), Zbigniew Hoffmann (województwo wielkopolskie). Dlatego Woidke początkowo obawiał się, jak ułoży się z nimi współpraca ${ }^{28} .1$ kwietnia 2016 roku koordynatorem ze strony Polski ds. współpracy transgranicznej i regionalnej został sekretarz stanu z ministerstwa spraw wewnętrznych i administracji dr Jakub Tadeusz Skiba, który sprawował funkcję do października 2017 roku, gdy został prezesem Polskiej Wytwórni Papierów Wartościowych $^{29}$. Wakat na stanowisku koordynatora ds. współpracy transgranicznej i regionalnej trwał do 27 marca 2018 roku, gdy funkcję przyjęła Renata Szczęch ${ }^{30}$. Tak wiele zmian personalnych wśród polskich polityków zajmujących się relacjami polsko-niemieckimi nie było korzystne. Woidke wykazał się jednak umiejętnością współpracy i nawiązywania kontaktów i w polskich mediach informacje na temat jego działań są wyważone.

W wyniku przeprowadzonych w RFN 24 października 2017 roku wyborów parlamentarnych po długim okresie kształtowania się nowego rządu następca Sigmara Gabriela Heiko Maas zaproponował Dietmarowi Woidkemu dalsze sprawowanie funkcji koordynatora ds. współpracy polsko-niemieckiej.

\section{Reakcja Dietmara Woidkego na wybrane problemy podczas sprawowania funkcji koordynatora:}

\section{Rozlokowanie wojsk NATO na terytorium Polski}

2. Nauczanie języka polskiego w Niemczech

3. Spór dotyczący Trybunału Konstytucyjnego w Polsce

4. Przystanek Woodstock

27 EU-Verfahren gegen Polen „Ratschläge von außen zu gebe ist falsch”...

28 Ibidem; Grußwort von Dietmar Woidke bei der Eröffnung des Spitzentreffens der Oder -Partnerschaft in Breslau, 27. Januar 2016, http://www.auswaertiges-amt.de/DE/AAmt/Koordinatoren/D-PL-Koordinator/Aktuell/160127_Oderpartnerschaft.html (dostęp: 14 września 2017).

29 Jakub T. Skiba zasiadał w zarządzie Narodowego Banku Polskiego, pracował w Najwyższej Izbie Kontroli, Ministerstwie Spraw Zagranicznych, Stałym Przedstawicielstwie RP przy ONZ, Ministerstwie Spraw Wewnętrznych i Administracji, Kancelarii Prezesa Rady Ministrów, Głównym Urzędzie Statystycznym. Jest autorem książki Itinerarium. Moja podróż w głąb Europy (Wydawnictwo Jedność, Kielce 2012).

30 Renata Szczęch jest prawnikiem i dyplomatą. Sprawowała funkcję podsekretarza stanu w ministerstwie rodziny, pracy i polityki społecznej (grudzień 2015-wrzesień 2016), podsekretarza stanu w ministerstwie spraw zagranicznych, a od 24 października 2017 roku jest podsekretarzem stanu w Ministerstwie Spraw Wewnętrznych i Administracji. 


\section{Rozlokowanie wojsk NATO na terytorium Polski}

Niestabilna sytuacja na Ukrainie wpłynęła na decyzję NATO, by rozlokować dodatkowe wojska w Polsce. Z niemieckiego portu w Bremerhaven w styczniu 2017 roku ruszyły przez Brandenburgię do Polski amerykańskie czołgi. Wtedy Woidke wyraził zaniepokojenie $\mathrm{z}$ powodu przemieszczania się pojazdów pancernych, powątpiewając przy tym, że ich obecność nie wpłynie na polepszenie stanu bezpieczeństwa. Jego opinia została odebrana jako zgodna z linią polityczną niemieckiej socjaldemokracji, postrzeganej jako ugrupowanie dążące do podtrzymania dobrej współpracy na linii Berlin-Moskwa. Poparła go pacyfistyczna partia Die Linke, ale skrytykowała CDU. Polityk Zielonych, Axel Vogel, zaznaczył, że potrzebna jest dyplomacja między Rosją i NATO, która osłabi w Polsce i państwach bałtyckich poczucie zagrożenia ze strony Rosji. Zaznaczył także, że Woidke powinien swoje obawy z powodu stacjonowania wojsk pancernych NATO w Polsce przedstawić premier Beacie Szydło. Także niemieckie środowisko naukowe bacznie przysłuchiwało się wypowiedziom premiera Brandenburgii. Historyk Manfred Görtemaker zaznaczył, że ,pacyfizm i moralizatorstwo” nie są skuteczne, a wobec Rosjan trzeba prowadzić politykę realizmu ${ }^{31}$.

19 stycznia 2017 roku Woidke w przemówieniu przed parlamentem krajowym Brandenburgii zadeklarował, że w NATO nie ma „sojuszników drugiej klasy”. Tłumaczył słuchaczom, że Polacy, którzy utracili w przeszłości na 123 lata niepodległość, cenią suwerenność. Zwrócił uwagę, że po aneksji Krymu przez Rosję wzrosło poczucie zagrożenia w Polsce. Polityk zadeklarował wsparcie wobec Polski i państw bałtyckich ${ }^{32}$.

\section{Nauczanie języka polskiego w Niemczech}

Dostęp do nauczania w języku ojczystym obok dostępu do rynku pracy w znaczny sposób determinuje poziom życia na emigracji. W Polsce nauczanie języka niemieckiego jest rozpowszechnione. Natomiast polski koordynator, Jakub Skiba, ubolewał, że działania strony niemieckiej w celu promowania nauczania języka polskiego są nieskuteczne. Jednak zdaniem Magdaleny Telus, przewodniczącej Federalnego Związku Nauczania Języka Polskiego, przystąpienie Polski do UE wpłynęło na zwiększenie atrakcyjności języka polskiego w Niemczech i przyniosło szanse na poprawę sytuacji w zakresie jego nauczania. Dietmar Woidke deklaruje, że popiera nauczanie języka polskiego na terytorium Niemiec, a zwłaszcza w obszarze przygranicznym. Niemcy wskazują, że to w gestii krajów związkowych, a nie rządu federalnego leży wywiązanie się

31 Historiker kritisiert Woidkes Panzer-Kommentar, „Märkische Allgemeine”, 7. Januar 2017 http://www.maz-online.de/Brandenburg/Historiker-kritisiert-Woidkes-Panzer-Kommentar (dostęp: 14 września 2017); Niemcy nie chcą amerykańskich czołgów w Polsce. Lewica zapowiada protesty na trasie ich przejazdu, 6 stycznia 2017, „Newsweek online”, http://www.newsweek.pl/swiat/niemiecka-lewica-i-premier-brandenburgii-nie-chca-czolgow-usa-w-polsce, artykuly,403174,1.html (dostęp: 14 września 2017).

32 Dietmar Woidke zur Solidarität mit Polen und den drei baltischen Staaten: „Es gibt keine NATO: Verbündeten zweiter Klasse, 19. Januar 2017, http://www.auswaertiges-amt.de/DE/AAmt/ Koordinatoren/D-PL-Koordinator/Aktuell/170119-Rede_Brandenburger_Landtag.html (dostęp: 14 września 2017). 
z obowiązku umożliwienia nauczania języka polskiego, który został sformułowany w Traktacie o dobrym sąsiedztwie w 1991 roku. W Niemczech należy rozróżnić nauczanie języka polskiego jako jezyka ojczystego lub jako jezyka obcego. Oferta nauczania jezyka polskiego w krajach związkowych RFN jest zróżnicowana, np. w Bremie język polski był nauczany jako język obcy, a w Dolnej Saksonii jako język ojczysty ${ }^{33}$. Na terenie Brandenburgii można się uczyć języka polskiego jako języka ojczystego lub jako języka obcego w wybranych szkołach w Schwedt, Gubinie, Neuzelle oraz we Frankfurcie nad Odrą. Polacy są zdania, że oferta powinna zostać rozszerzona we wszystkich krajach związkowych. Woidke postulował zwiększenie liczby szkół posiadających ofertę nauczania języka polskiego. Polityk składał wizyty w szkołach, gdzie zabiegał o realizację polsko-niemieckich projektów edukacyjnych. Poparł „Strategię nauczania języka polskiego jako języka ojczystego" Sekretariatu Stałej Konferencji Ministrów Kultury, Nauki, Oświaty Krajów Związkowych RFN) z dnia 20 czerwca 2013 roku. Ten dokument został wypracowany we współpracy z Polsko-Niemieckim Komitetem ds. Edukacji (częścią Polsko-Niemieckiej Komisji Międzyrządowej ds. Współpracy Regionalnej i Przygranicznej) ${ }^{34}$. Dietmar Woidke opowiadał się za inicjatywami środowisk społecznych i naukowych, które postulują rozpowszechnianie nauki języka polskiego w Niemczech. 1 czerwca 2017 roku podczas spotkania premierów krajów związkowych z kanclerz Angelą Merkel zaproponował poszerzenie oferty nauczania języka polskiego w krajach związkowych, które zgłoszą takie zapotrzebowanie. Woidke był zwolennikiem projektu PolenMobil, który polega na rozpropagowaniu języka polskiego w niemieckich szkołach. Patronem projektu jest Instytut Polsko-Niemiecki w Darmstadt ${ }^{35}$.

\section{Spór dotyczący Trybunalu Konstytucyjnego w Polsce}

25 października 2015 roku odbyły się w Polsce wybory parlamentarne, a końcowi kadencji parlamentu VII okresu legislacyjnego i rozpoczęciu prac parlamentu VIII kadencji towarzyszył spór dotyczący wyłaniania sędziów Trybunału Konstytucyjnego. Konflikt o to, kto ma prawo wyboru sędziów i na jakiej podstawie prawnej, wzbudził protesty społeczne i zaangażował przedstawicieli wielu środowisk, m.in. prawniczych

33 M. Telus, Język polski w Niemczech, http://www.polska-niemcy-interakcje.pl/articles/show/50 (dostęp: 12 sierpnia 2019); K. Schöll-Mazurek, Między polityka integracyjną a polityka polonijną. Sytuacja najnowszych polskich migrantów w Niemczech $w$ wybranych obszarach po 2011 roku, Księgarnia Akademicka, Kraków 2016, s. 159-160.

34 Por. Strategia nauczania języka polskiego jako ojczystego w RFN, https://berlin.msz.gov.pl/pl/ aktualnosci/strategia_nauczania_jezyka_polskiego_jako_ojczystego_w_rfn (dostęp: 15 września 2017).

35 B. Kerski, A. Szczepański, Rozmowa z Dietmarem Woidke...; Rozmowa z wiceministrem spraw wewnętrznych Jakubem Skiba, koordynatorem rząu RP do spraw relacji polsko-niemieckich, „Dialog” 2016/2017, nr 4, s. 40-43; K. Schöll-Mazurek, Między polityka integracyjna..., s. 159-160; B. Cöllen, Język polski w Niemczech. Polonia domaga się realizacji Traktatu, 2 września 2016, https:// www.dw.com/pl/język-polski-w-niemczech-polonia-domaga-się-realizacji-traktatu/a-19496590 (dostęp: 15 września 2017); M. Matzke, RFN. Będzie szersza oferta nauczania polskiego, 3 czerwca 2017, https://www.dw.com/pl/rfn-będzie-szersza-oferta-nauczania-polskiego/a-39096383 (dostęp: 15 września 2017). 
i naukowych oraz szereg dyskusji poza granicami Polski, także na forum Unii Europejskiej. Dietmar Woidke początkowo starał się nie zadrażniać sytuacji i podkreślał, że nie należy pouczać z zewnątrz Polaków, ponieważ w ich mentalności tkwi umiłowanie wolności oraz duma narodowa. Jednak sprawa dla niemieckiego polityka skomplikowała się, gdy Komisja Europejska zareagowała na wydarzenia wokół polskiego Trybunału Konstytucyjnego. Z powodu sporu między zwolennikami obozów skupionych wokół dwóch rywalizujących partii - Platformy Obywatelskiej oraz Prawa i Sprawiedliwości o to, kto w sposób legalny usiłował obsadzić wakaty sędziowskie, Komisja Europejska zdecydowała wszcząć procedurę zbadania stanu praworządności w Polsce. Woidke wypowiedział się wtedy, że instytucje unijne mają prawo - na mocy Traktatu Lizbońskiego - do kontroli przestrzegania prawa przez państwa członkowskie UE ${ }^{36}$.

\section{Przystanek Woodstock}

Dietmar Woidke przyjął $\mathrm{z}$ entuzjazmem przygotowania do zaplanowanego na 3-5 sierpnia 2017 roku dwudziestego trzeciego Festiwalu „Przystanek Woodstock” w Kostrzynie nad Odrą. Zauważył, że impreza stała się popularna i sprzyja integracji i spotkaniom polsko-niemieckim. Woidke zwrócił się w liście do koordynatora Skiby z propozycją wsparcia organizacyjnego festiwalu poprzez uzupełnienie składu polskich służb pożarowych służbami z Brandenburgii. Współpraca polsko-niemieckich służb podczas poprzednich edycji „Przystanku Woodstock” odbywała się poprawnie. Dlatego ze zdziwieniem strona niemiecka przyjęła odpowiedź polskiego sekretarza stanu Jakuba Skiby z 27 lipca 2017 roku, że tym razem organizacja służb ratunkowych zostanie przygotowana w oparciu o środki krajowe. Skiba argumentował, że w obliczu zagrożenia terrorystycznego łatwiej będzie zapewnić bezpieczeństwo, nie korzystając z pomocy RFN i nie nadając przygotowaniom organizacyjnym międzynarodowego wymia$\mathrm{ru}^{37}$. Ponadto zwrócił się on $\mathrm{w}$ liście o ,zapewnienie odpowiedniego standardu ochrony granicy polsko-niemieckiej $[\ldots] \mathrm{w}$ związku z sytuacją społeczną i demograficzną na niemieckich terenach przygranicznych w kontekście obecnego kryzysu migracyjnego ${ }^{38}$. Reakcja Skiby wzbudziła zdziwienie u piszącego od lat o relacjach polsko-niemieckich dziennikarza Uwe Rady, który wypomniał polskiemu sekretarzowi stanu niekonsekwencję. Dziennikarz podkreślił, że Jakub Skiba był zwolennikiem polsko-niemieckiej umowy o współpracy policji i często wypowiadał się wcześniej o potrzebie wspólnych polsko-niemieckich działan. Rada skomentował także, że „Przystanek Woodstock” nie jest imprezą popieraną przez Prawo i Sprawiedliwośćc ${ }^{39}$. Warto odnotować, że Woidke wystosował także list do uczestników festiwalu, w którym zauważył, że organizowa-

36 Justizreform im Nachbarland - Woidke: Polen lassen sich ihre Demokratie nicht nehmen, 25. Juli 2017, https://www.rbb24.de/politik/beitrag/2017/07/woidke--polen-werden-sich-ihre-demokratie-nicht-nehmen-lassen.html (dostęp: 15 września 2017).

37 List wiceministra Jakuba Skiby do Dietmara Woidke Premiera Kraju Związkowego Brandenburgii. 27 lipca 2017, https://www.mswia.gov.pl/pl/aktualnosci/16374,List-wiceministra-JakubaSkiby-do-Dietmara-Woidke-Premiera-Kraju-Zwiazkowego-Bra.html (dostęp: 14 września 2017). 38 Ibidem.

39 U. Rada, Open-Air-Festival in Kostrzyn. Warschau mag kein Woodstock, „Der Tagesspiegel online", 2 sierpnia 2017, http://www.taz.de/!5432122/ (dostęp: 14 września 2017); 
nie „Przystanku Wooodstock” przyczynia się do kształtowania otwartości i promowania wolontariatu $^{40}$. Sprawa współpracy między strażą pożarną z Polski i Niemiec ujawniła różnice w postrzeganiu bezpieczeństwa i kondycji współpracy. Wynikała częściowo $\mathrm{z}$ umacniania się $\mathrm{w}$ polskim dyskursie opinii o wzrastaniu znaczenia granic $\mathrm{w}$ związku z kryzysem migracyjnym w Europie.

\section{Wnioski}

Dietmar Woidke zabiega o dobry wizerunek relacji polsko-niemieckich. Często podkreśla znaczenie przeszłości w relacjach polsko-niemieckich i akcentuje, że Niemcy świadomi swojej trudnej przeszłości powinni budować społeczeństwo obywatelskie oraz dobre relacje z sąsiadami. Wypowiada się podczas rocznic wydarzeń historycznych. 31 sierpnia 2017 roku, w dniu poprzedzającym rocznicę napaści Niemiec na Polskę, polityk zaznaczył, że także obecnie istnieje wiele zagrożeń dla międzynarodowego bezpieczeństwa. Przypominając o konfliktach w Afryce, na Bliskim Wschodzie, w Afganistanie czy na wschodzie Ukrainy, wskazywał na potrzebę budowania kultury bezpieczeństwa w oparciu o środki, takie jak „dyplomacja i budowanie zaufania"41.

Często powołuje się na zawarty w 1991 roku Traktat o dobrym sąsiedztwie i przyjaznej współpracy oraz instytucjonalny dorobek współpracy, który został zbudowany w oparciu o ten dokument. Zwraca m.in. uwagę na celowość działania Polsko-Niemieckiej Współpracy Młodzieży, Forum Polsko-Niemieckiego, Partnerstwa Odry. Swoje projekty i pomysły inicjuje poprzez działalność Polsko-Niemieckiej Komisji Międzyrządowej ds. Współpracy Regionalnej i Przygranicznej oraz jej czterech komitetów. Regularnie odwiedza Polskę, zwłaszcza obszar na pograniczu polsko-niemieckim. Unika wypowiedzi, które mogłyby burzyć wizerunek dobrosąsiedzkich relacji, co czasem powoduje, że jego głos i opinie o sporach w relacjach polsko-niemieckich jest mało słyszalny. Na wizerunek i efektywność działania współpracy polsko-niemieckiej, którą koordynuje Dietmar Woidke, wpłynęły zmiany na polskiej scenie politycznej - zarówno wynikające ze zmiany rządu, jak i kanałów komunikacji, gdy rolę koordynatorów po polskiej stronie przejęli sekretarze stanu z MSWiA. Tym samym koordynator ze strony RFN jest powoływany przez niemiecki urząd spraw zagranicznych, a przedstawiciel Polski działa poprzez struktury MSWiA.

40 Streit über grenzüberschreitendes Rockfestival. „Woidke wendet sich wegen „Haltestelle Woodstock" an Polen, 21. Juli 2017, https://www.rbb24.de/politik/beitrag/2017/07/woidke-wendet-sich-zu-haltestelle-woodstock-an-polen.html (dostęp: 14 września 2017); „List dr. Dietmara Woidke do gości festiwalu", http://lubuskie.pl/uploads/pliki/Biuro_prasowe/skan.pdf (dostęp: 14 września 2017); W. Szymański, Dietmar Woidke: Niepokoi mnie sprawa Przystanku Woodstock, 30 lipca 2017, http://www.dw.com/pl/dietmar-woidke-niepokoi-mnie-sprawa-przystanku -woodstock/a-39898591 (dostęp: 14 września 2017).

41 „Woidke warnt zum Antikriegstag vor Drohgebärden”, 31. August 2017, http://www.berliner-zeitung.de/berlin/woidke-warnt-zum-antikriegstag-vor-drohgebaerden-28255698 (dostęp: 15 września 2017). 


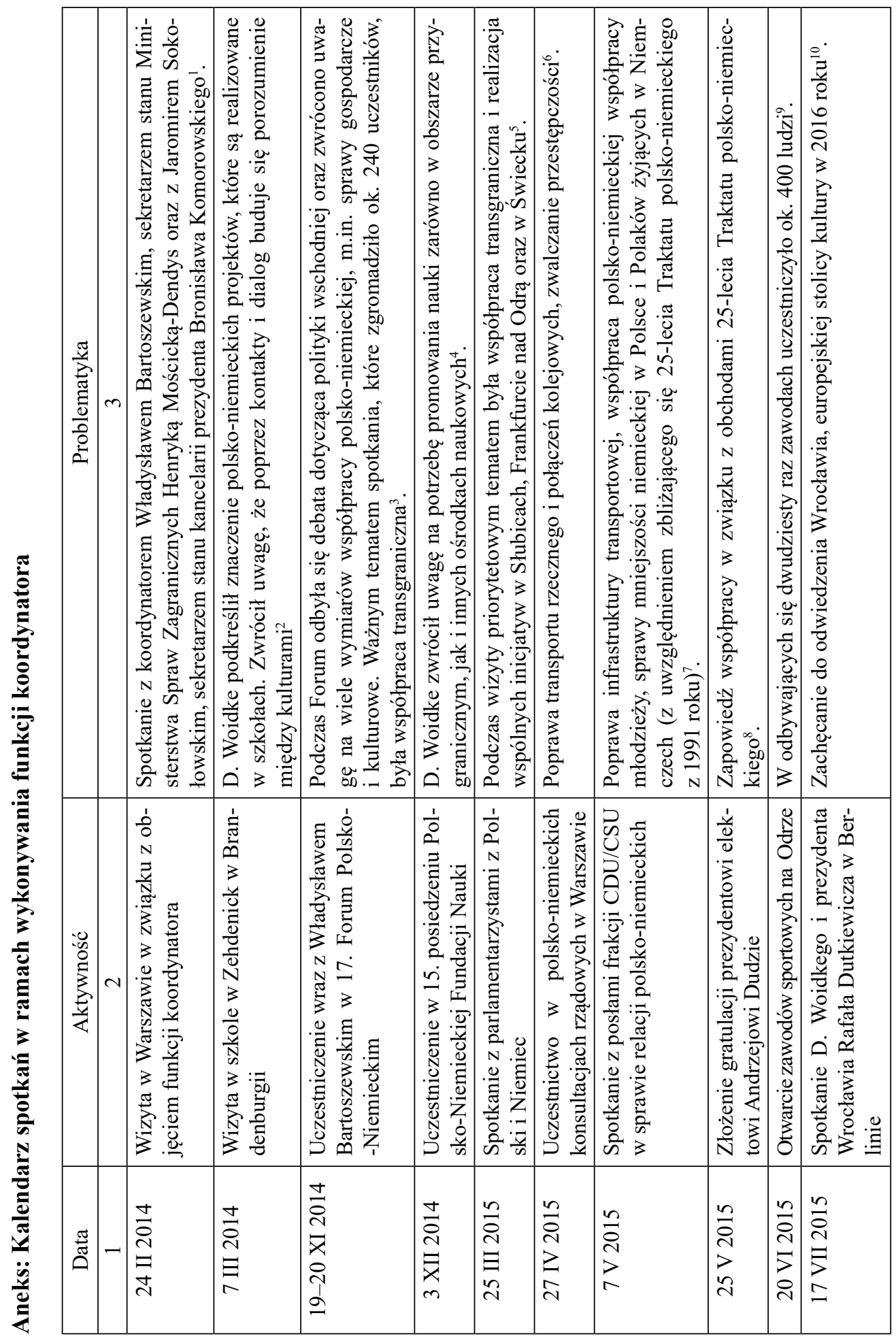




\begin{tabular}{|c|c|c|c|c|c|c|c|c|}
\hline$m$ & 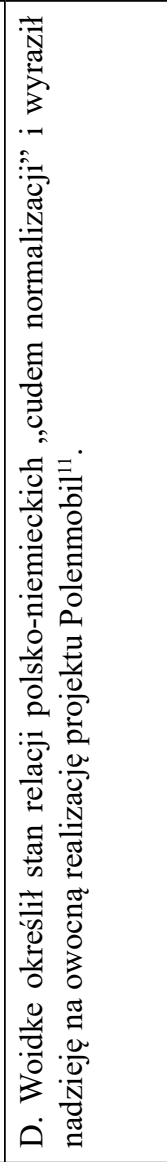 & 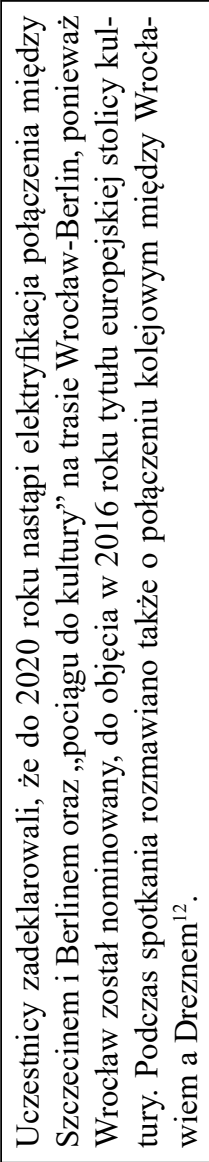 & 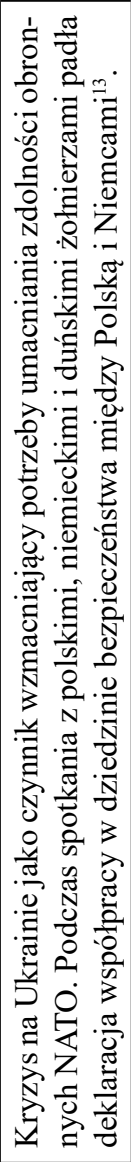 & 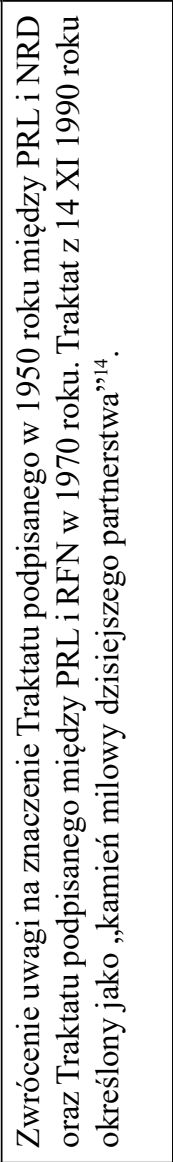 & 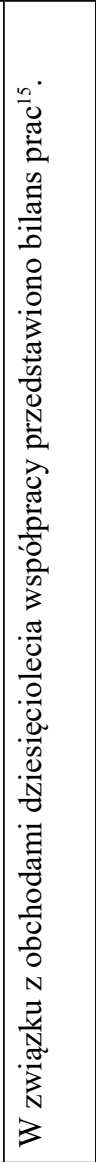 & 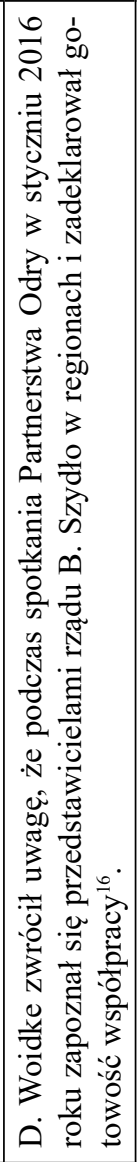 & 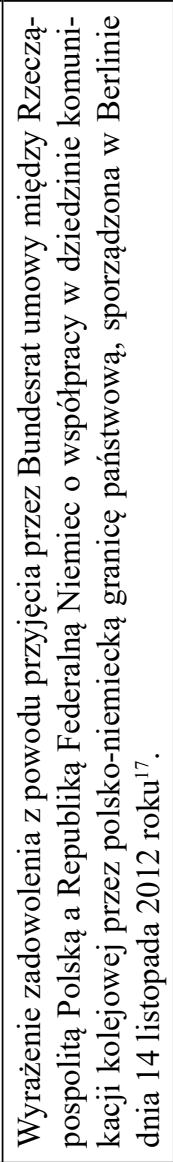 & 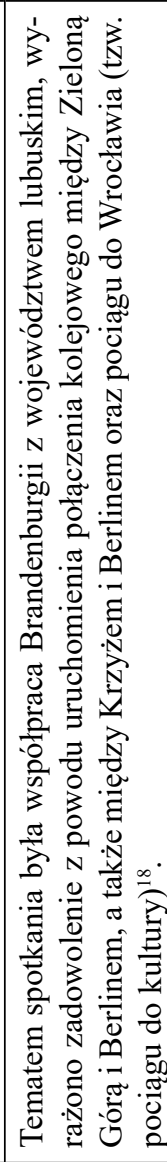 \\
\hline$N$ & 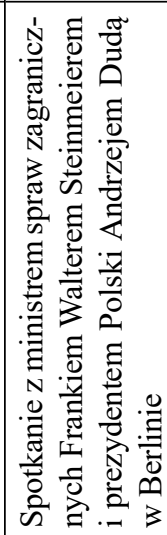 & 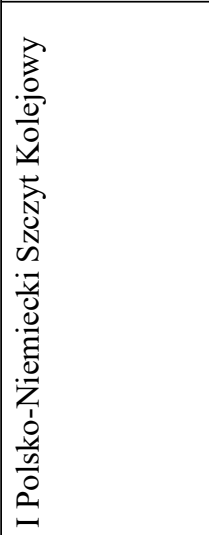 & 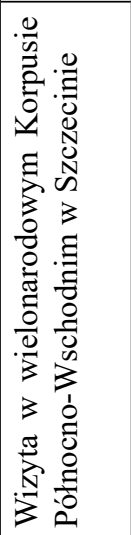 & 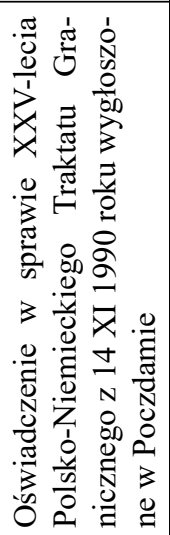 & 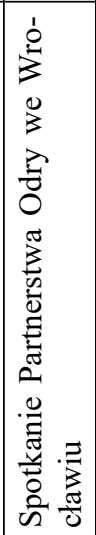 & 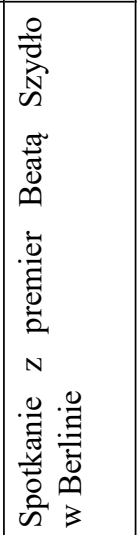 & 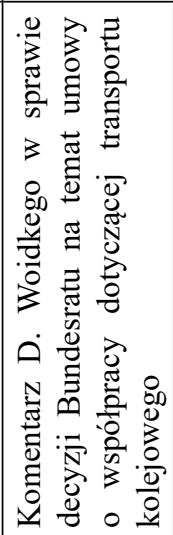 & 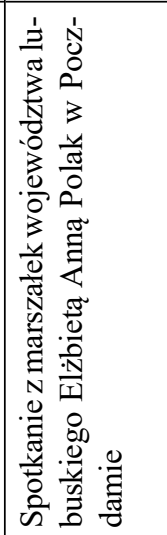 \\
\hline- & 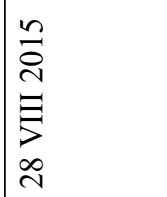 & 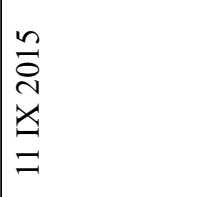 & 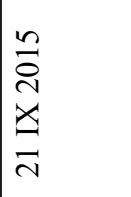 & 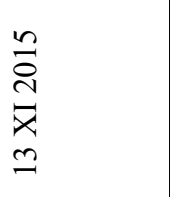 & 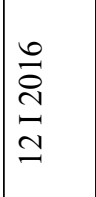 & 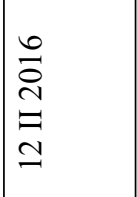 & 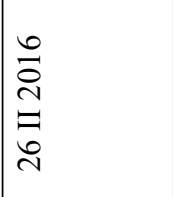 & $\begin{array}{l}\tilde{N} \\
\Xi \\
\end{array}$ \\
\hline
\end{tabular}




\begin{tabular}{|c|c|c|c|c|}
\hline$m$ & 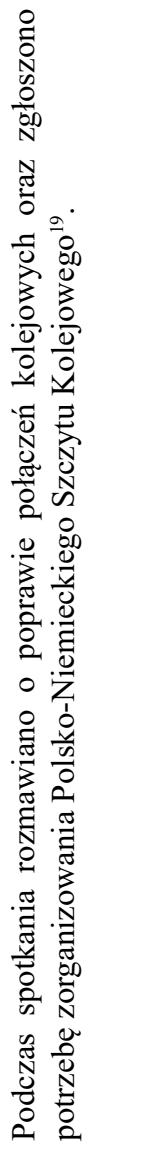 & 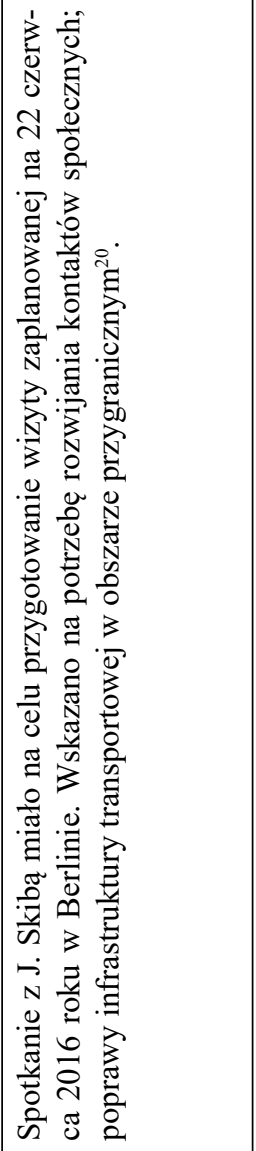 & 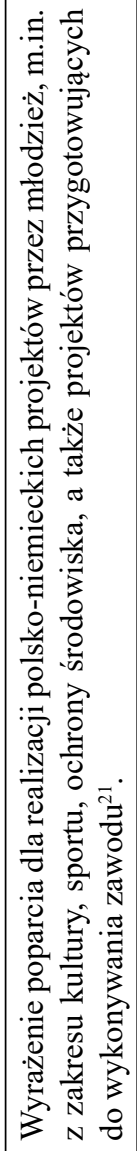 & 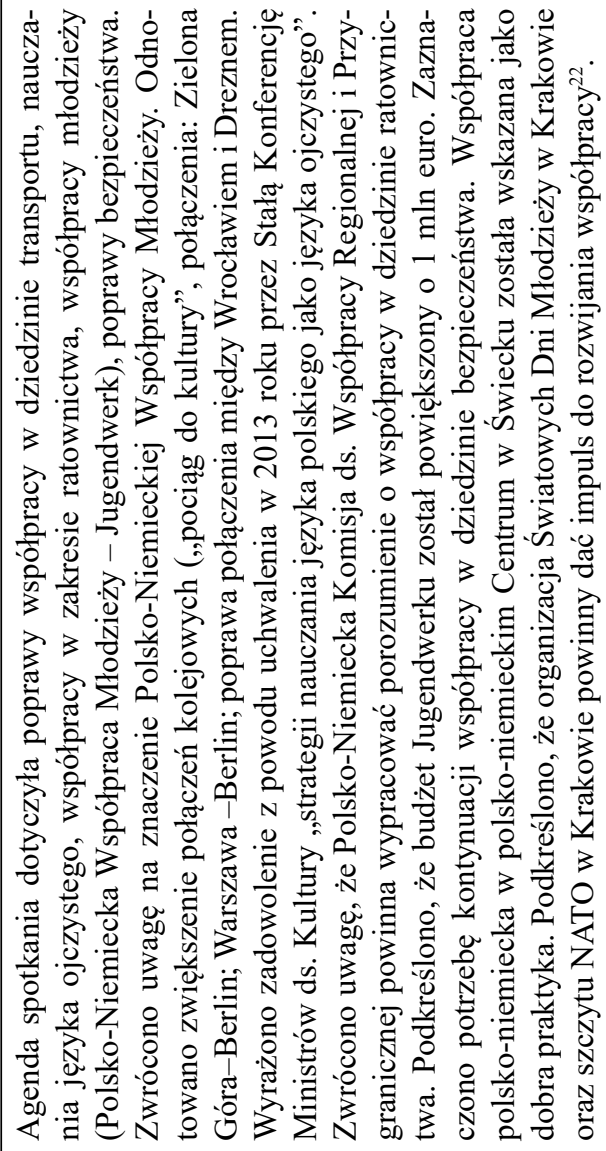 \\
\hline$N$ & 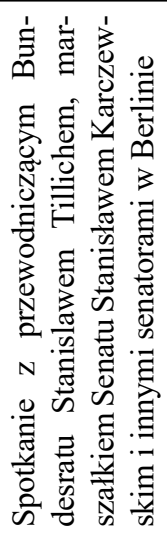 & 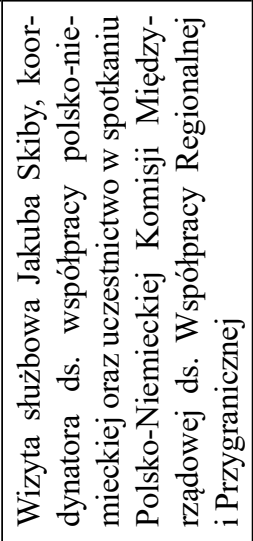 & 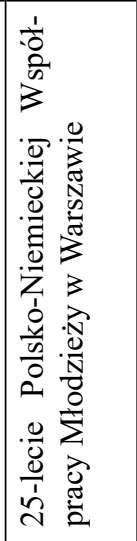 & 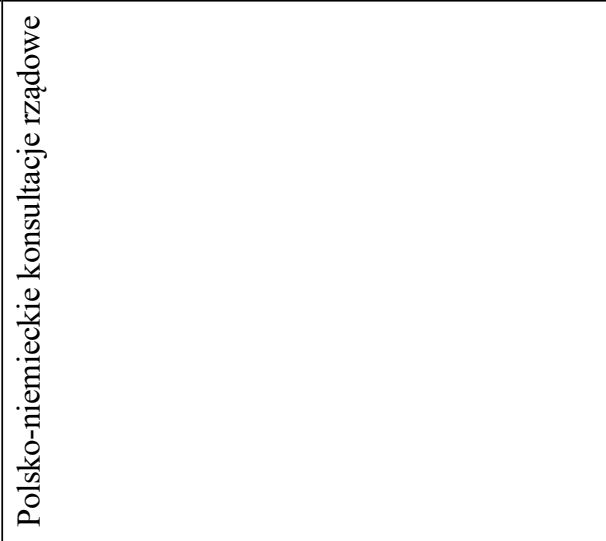 \\
\hline- & 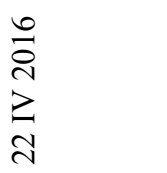 & 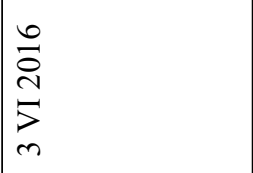 & 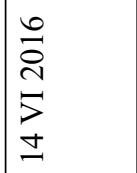 & 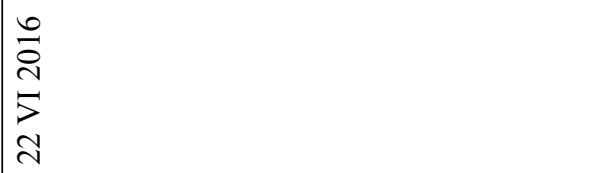 \\
\hline
\end{tabular}




\begin{tabular}{|c|c|c|c|c|c|c|c|c|c|}
\hline$m$ & 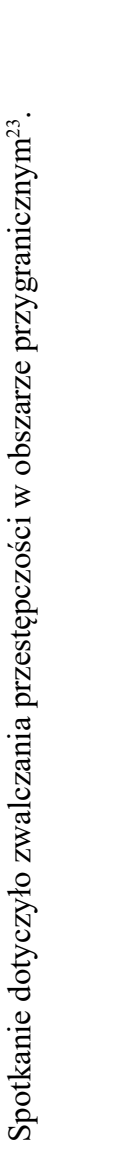 & 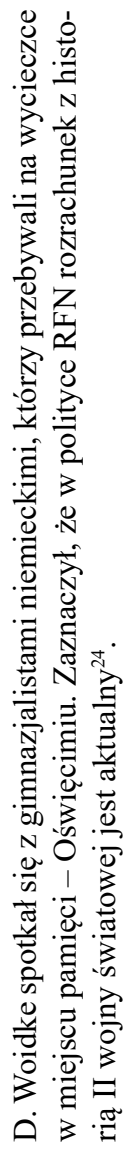 & 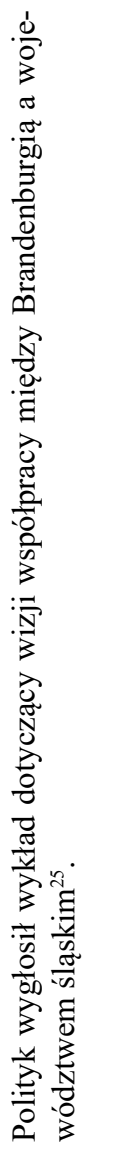 & 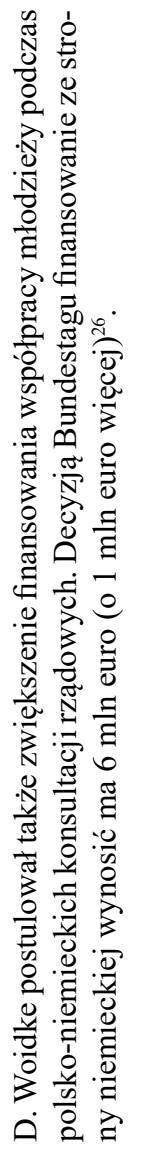 & 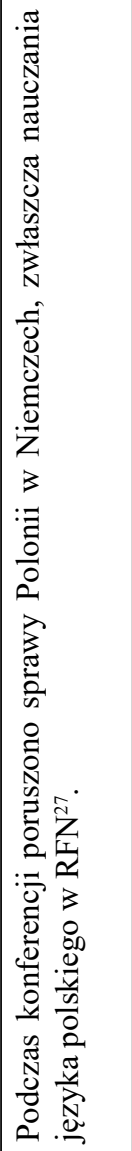 & 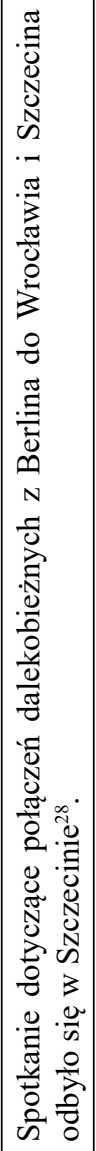 & 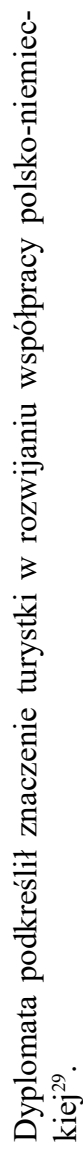 & 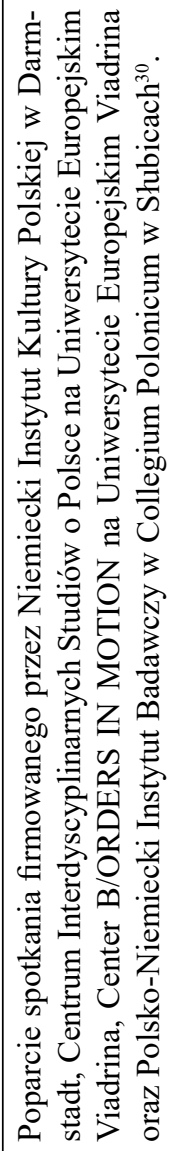 & 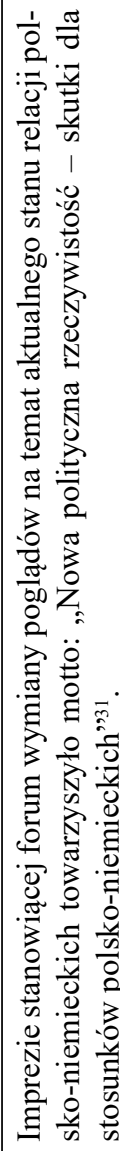 \\
\hline$v$ & 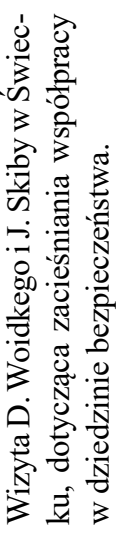 & 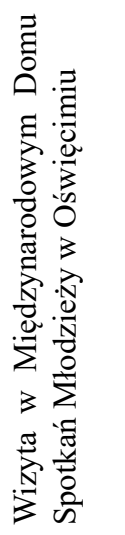 & 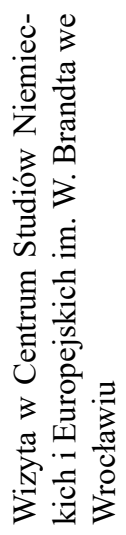 & 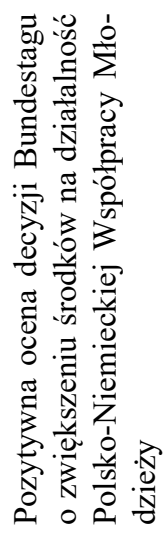 & 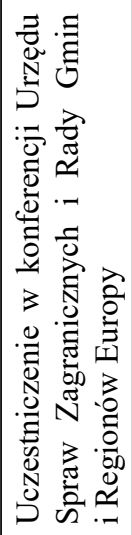 & 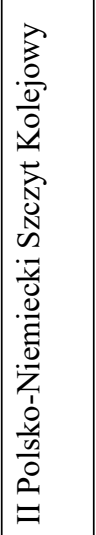 & 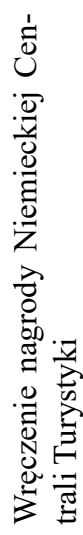 & 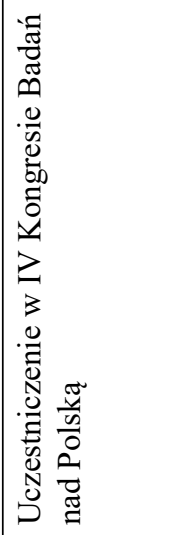 & 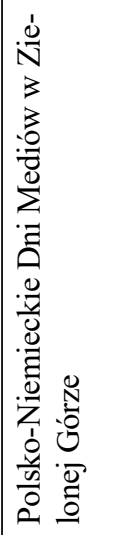 \\
\hline- & 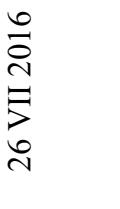 & $\begin{array}{l}0 \\
0 \\
0 \\
\vdots \\
j \\
0\end{array}$ & $\begin{array}{l}\vec{\circlearrowright} \\
\dot{\sim} \\
\dot{\sim}\end{array}$ & 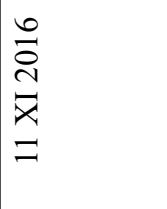 & 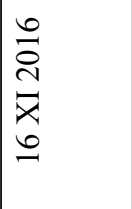 & 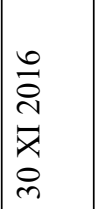 & $\begin{array}{l}\stackrel{へ}{\sim} \\
\ddot{\bar{x}} \\
\sim\end{array}$ & 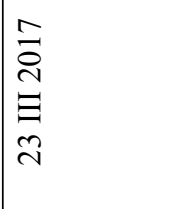 & $\begin{array}{l}\bar{N} \\
\stackrel{2}{N} \\
> \\
\bar{m}\end{array}$ \\
\hline
\end{tabular}




\begin{tabular}{|c|c|c|c|c|c|c|c|c|c|}
\hline$m$ & 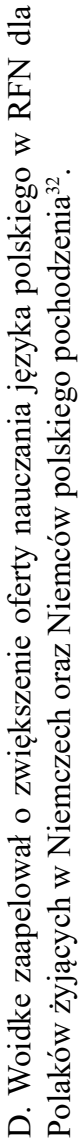 & 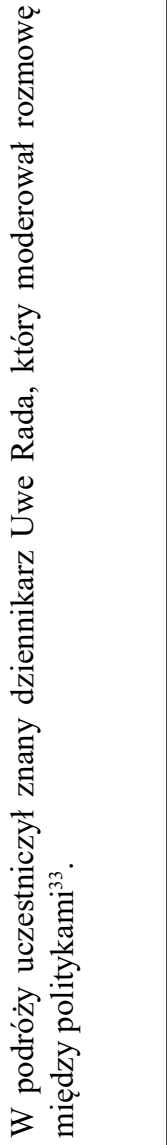 & 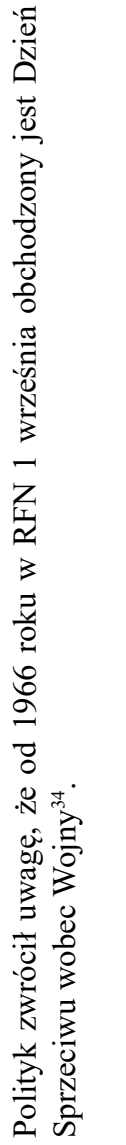 & 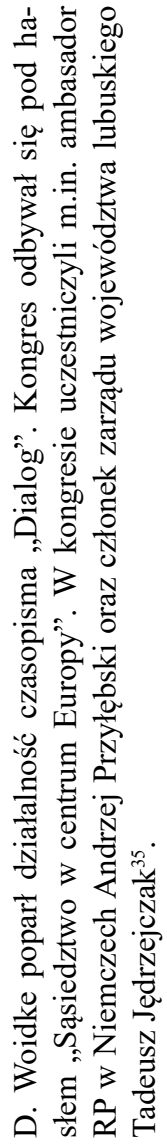 & 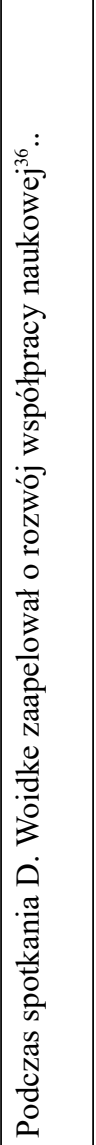 & 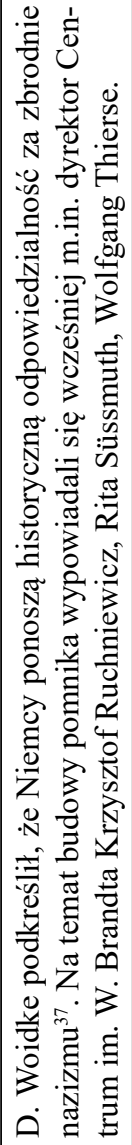 & 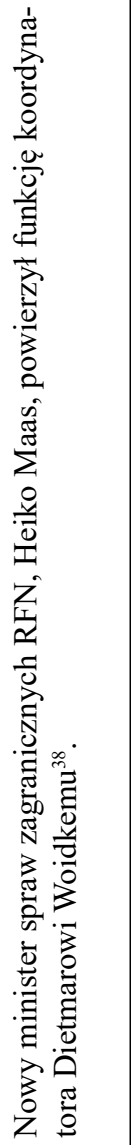 & 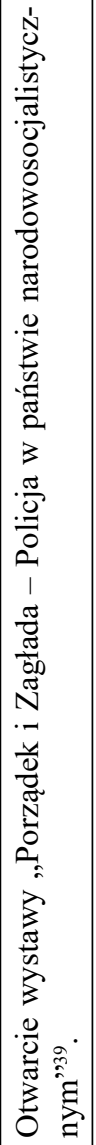 & 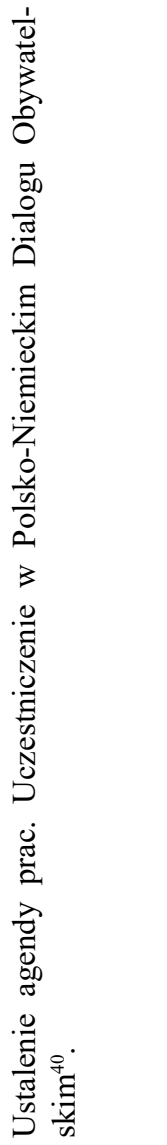 \\
\hline$N$ & 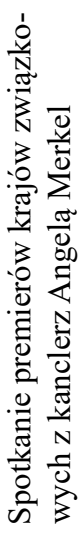 & 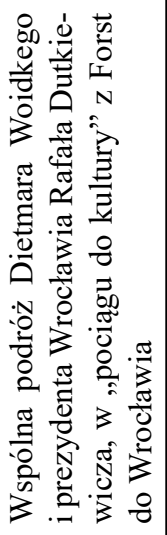 & 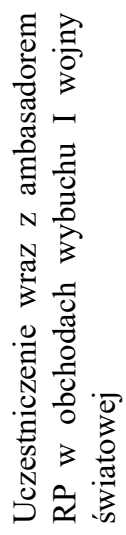 & 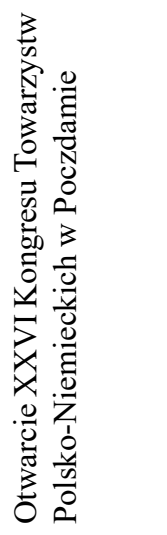 & 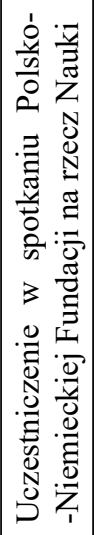 & 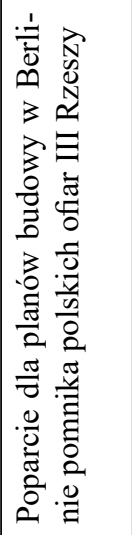 & 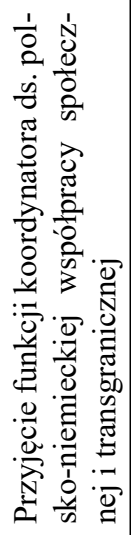 & 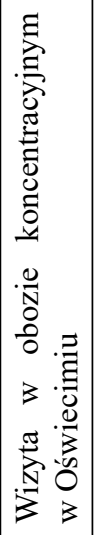 & 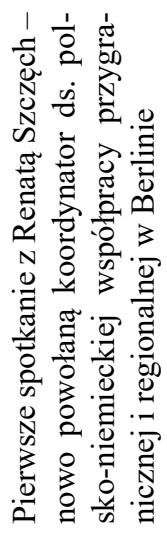 \\
\hline- & $\begin{array}{l}\text { 궁 } \\
\text { N } \\
>\end{array}$ & 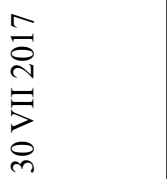 & $\begin{array}{l}\bar{\partial} \\
\text { ¿ } \\
=\end{array}$ & $\begin{array}{l}\bar{r} \\
\stackrel{\circ}{N} \\
\bar{x} \\
0\end{array}$ & 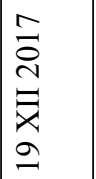 & 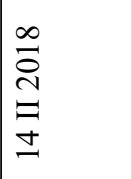 & $\begin{array}{l}\frac{\infty}{\sigma} \\
\stackrel{\curvearrowright}{\Xi} \\
\stackrel{n}{\sim}\end{array}$ & 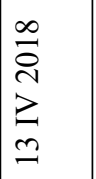 & $\begin{array}{l}\frac{\infty}{\sigma} \\
\stackrel{\sim}{>} \\
\underset{\sim}{\sim}\end{array}$ \\
\hline
\end{tabular}




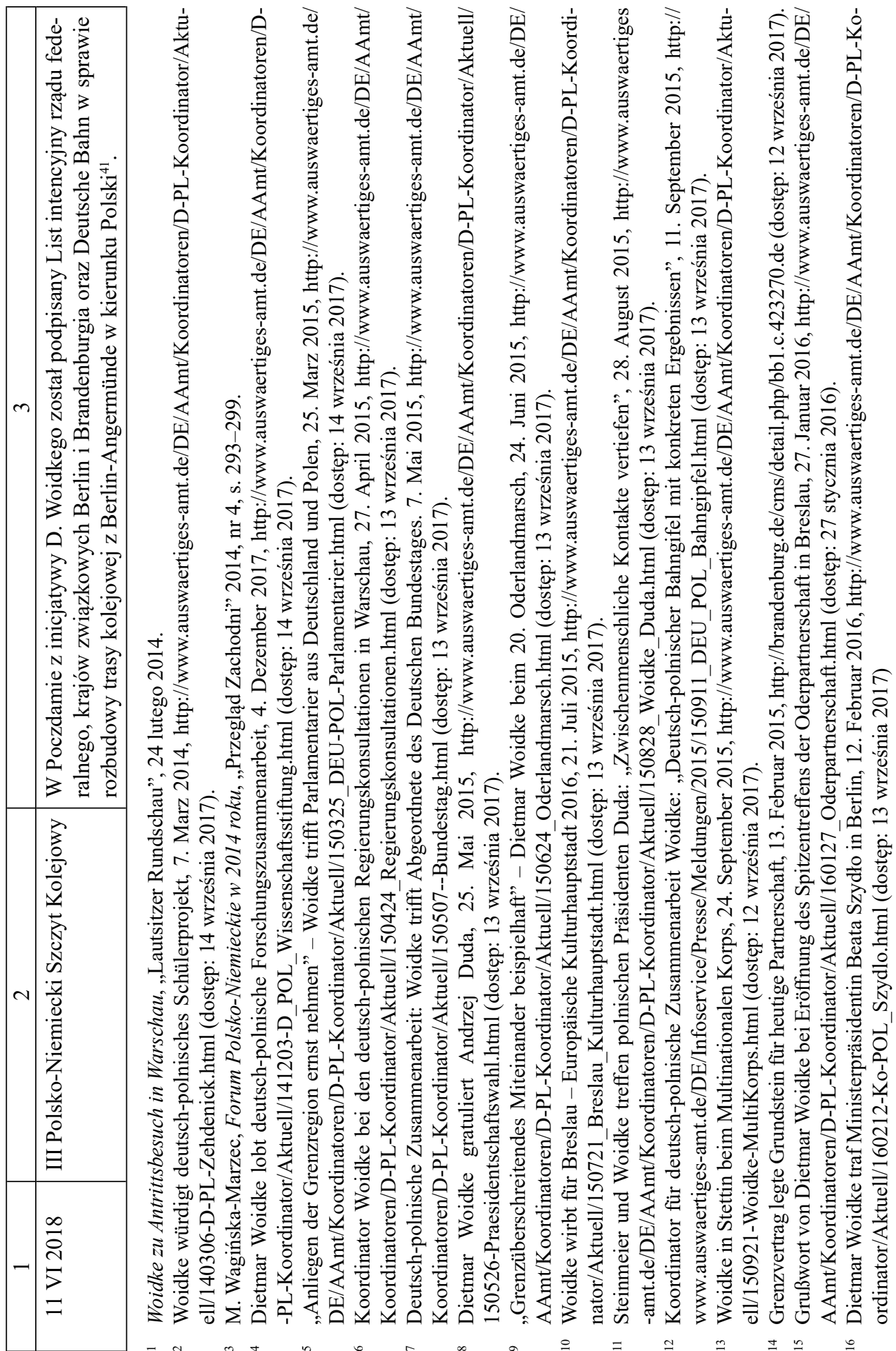




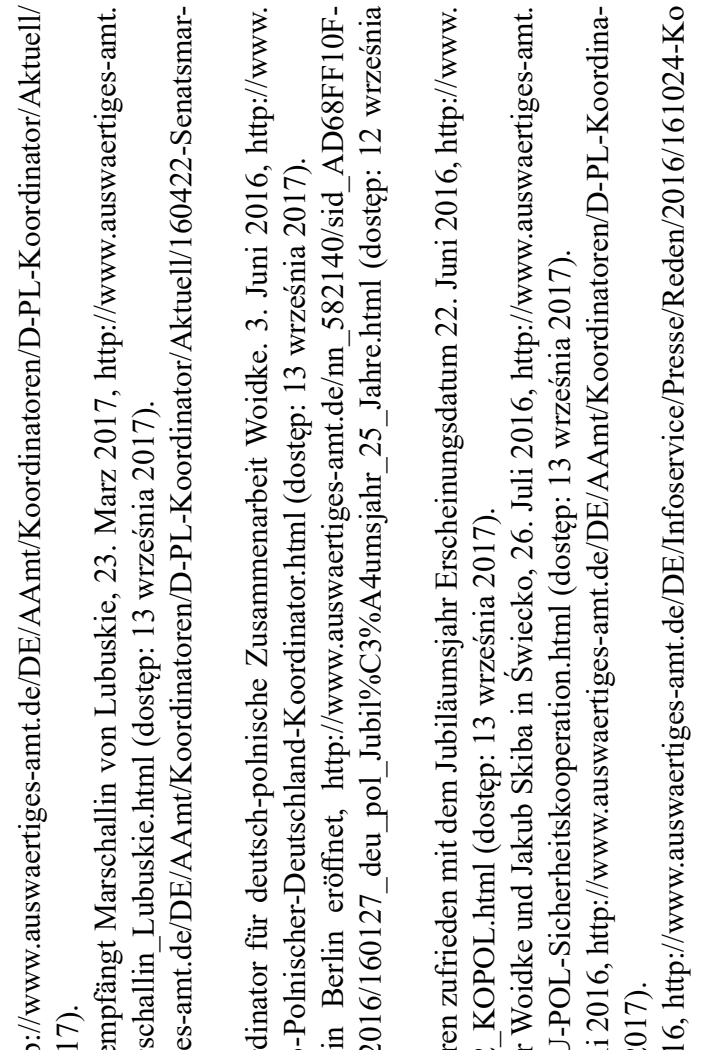

등

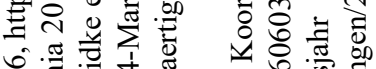

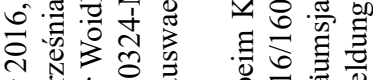

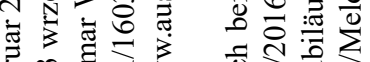

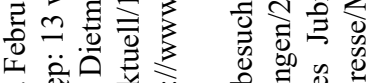

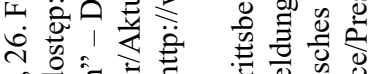

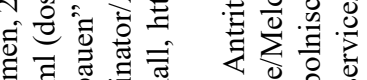

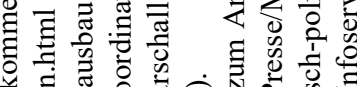

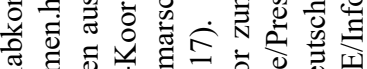

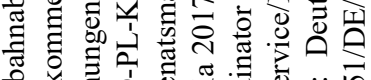

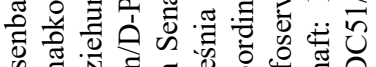

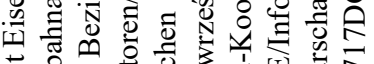

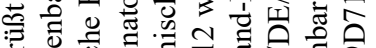
क. ه

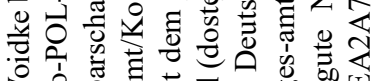

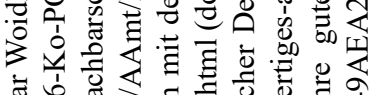

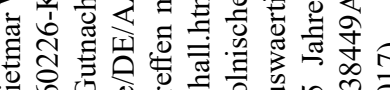

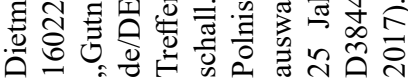

츤

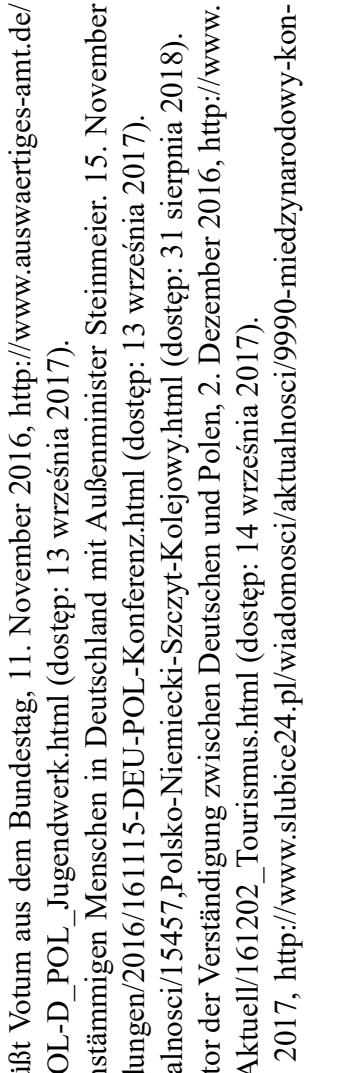

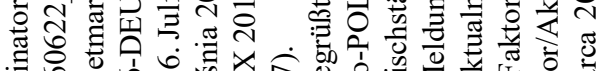

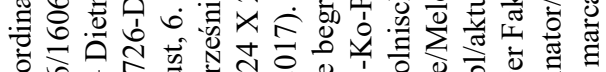

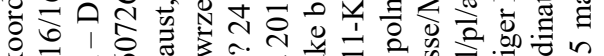

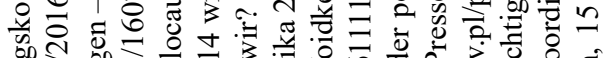

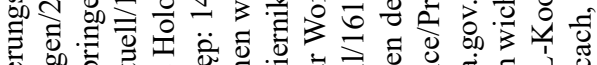
.

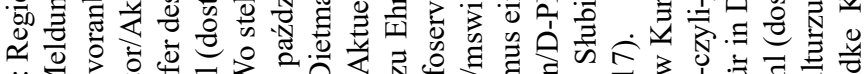

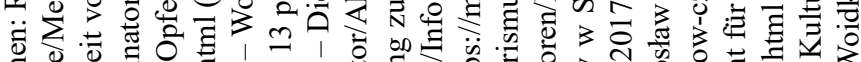
\%

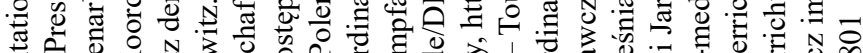

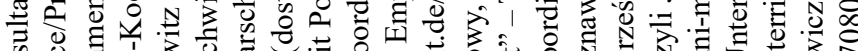

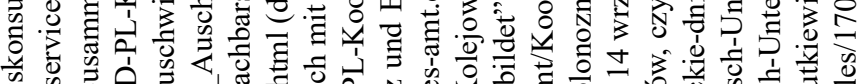

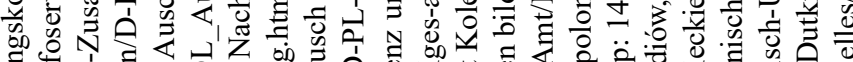

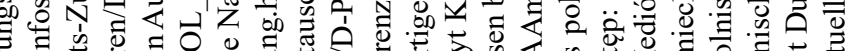

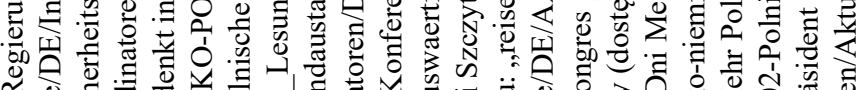

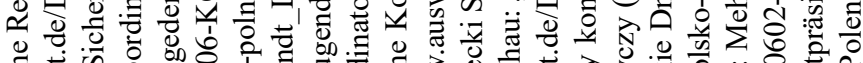

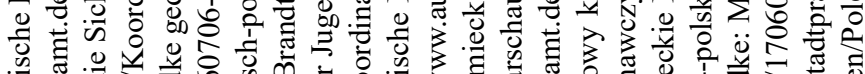

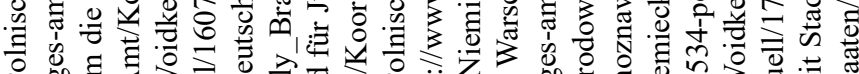

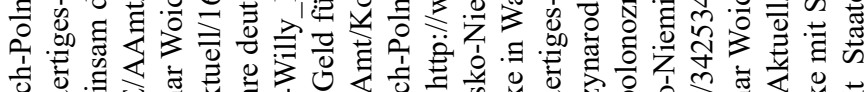

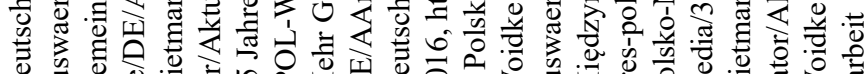

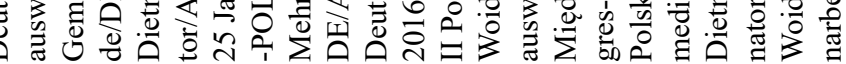




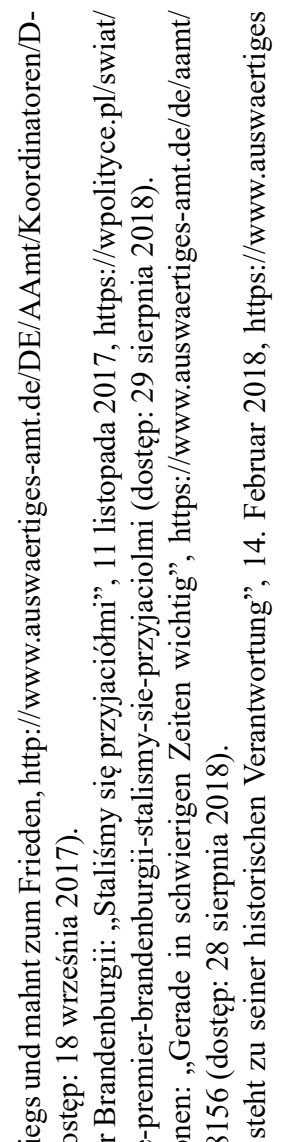

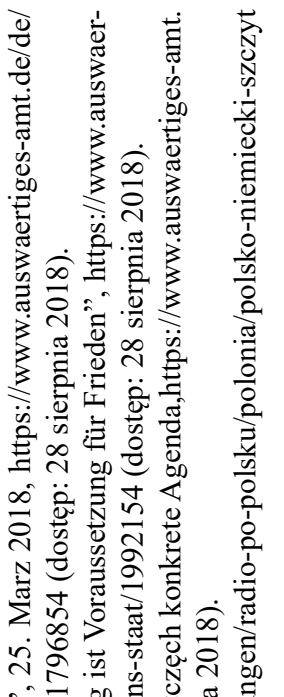

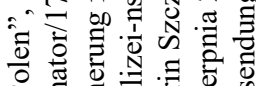

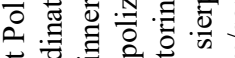

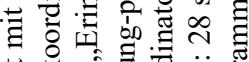
.

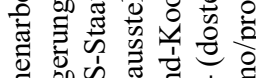

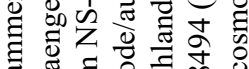

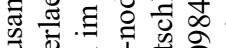

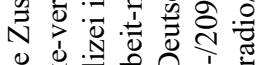

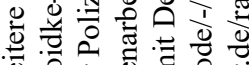

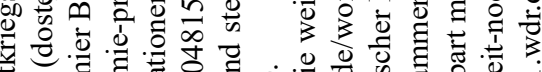

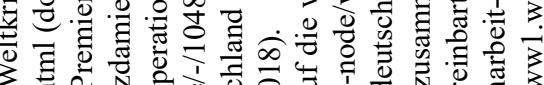

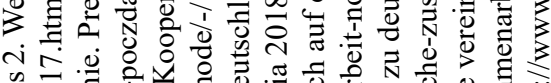

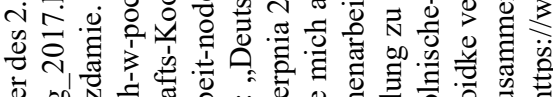

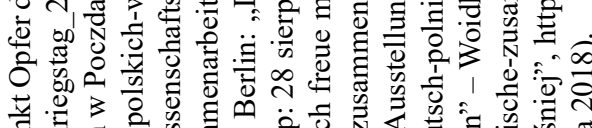

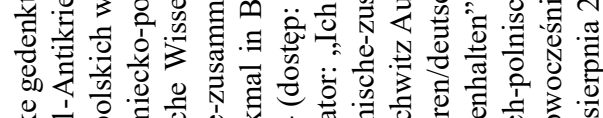

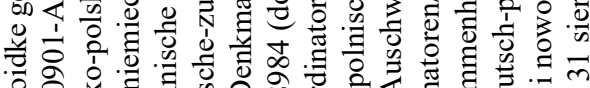

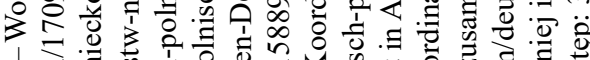

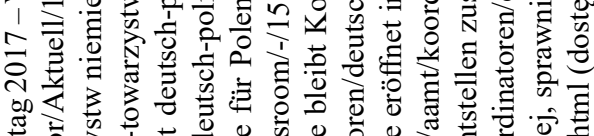

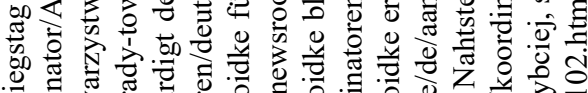

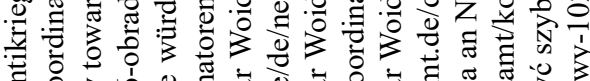

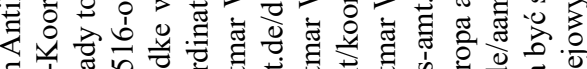

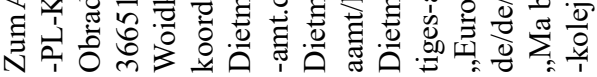

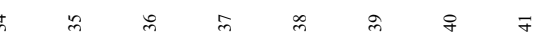


Abstract

Coordinator for Polish-German Cooperation: the Activity of Dietmar Woidke

The article concerns the function of the coordinator for Polish-German social and border cooperation. It analyses the activity of the third politician appointed to perform these tasks - Dietmar Woidke - a social democrat and a leading politician in Brandenburg. His activity is compared to those of Gesine Schwan and Cornelia Pieper.

Keywords: Polish-German relations, coordination. 